\title{
Characterizing Erythrophleum Suaveolens Charcoal as a Viable Alternative Fuel to Coke in Iron Melting In Nigeria
}

\author{
*Olorunnishola, A.A.G and **Akintunde, M.A \\ *Federal Polytechnic, Ado-Ekiti, Nigeria \\ **Federal University Of Technology, Akure, Nigeria
}

\begin{abstract}
An experimental study was conducted to characterize erythrophleum suaveolens (Gwaska) charcoal. The test was conducted for proximate analysis (involving the determination of moisture content, ash, volatile matter and fixed carbon) and ultimate analysis (involving the determination of carbon, hydrogen, oxygen, nitrogen sulphur and calorific value) of erythrophleum suaveolens charcoal. The determined values of moisture, ash, volatile matter and fixed carbon were $0.94 \%, 6.13 \%, 6.77 \%$ and $86.16 \%$ respectively. Also the determined values of carbon, hydrogen, oxygen, nitrogen, sulphur and calorific value were $77.5 \%, 9 \%, 5.48 \%, 1.89 \%$, $0.003 \%$ and $7158.6995 \mathrm{Kcal} / \mathrm{Kg}$ respectively. Therefore, the gwaska charcoal satisfies the blast furnace requirements for moisture, ash and sulphur in Nigeria. However, its volatile matter exceeds the specified limit except for Indian standard practice. The erythrophleum suaveolens charcoal's thermal properties showed that it could compete favourably with coke and therefore can be an excellent reducing fuel for the production of iron.

Keywords: Erythrophleum suaveolens charcoal, proximate analysis, ultimate analysis, coke
\end{abstract}

\section{Introduction}

Charcoal is dark grey residue consisting of carbon, and any remaining ash, obtained by removing water and other volatile constituents from animal and vegetation substances. Charcoal is usually produced by slow pyrolysis, the heating of wood or other substances in the absence of oxygen. It is usually an impure form of carbon as it contains ash; however, sugar charcoal is among the purest forms of carbon readily available, particularly if it is not made by heating but by a dehydration reaction with sulfuric acid to minimize introducing new impurities, as impurities can be removed from the sugar in advance. The resulting soft, brittle, lightweight, black, porous material resembles coal [20].

The primary sources of energy include; electricity, coal (coke), kerosene, gas, fuel wood (biomass) and solar energy in recent times [17]. According to Center for Agric. Development [CAD] [6], in developing countries, the predominant traditional sources of energy are fuel wood and charcoal, which are used primarily for cooking and heating homes. Most fuel users prefer charcoal to firewood because it does not produce much smoke, it can be ignited easily, it emits heat for a longer period of time and most importantly it is relatively cheap. Charcoal is the solid residue remaining when wood is carbonized or pyrolized under controlled conditions in a closed space such as charcoal kiln. According to Food and Agriculture Organization of the United Nations [FAO] [10], charcoal can be obtained from other organic substances such as coconut shell and bones, which provide very important and valuable charcoal for specialized uses, but wood is the most frequently used in developing countries. The physical and chemical properties of charcoal depend partly on the carbonization process. In Nigeria, charcoal has a multipurpose value as it can be used for cooking, roasting, dyeing and as the major source of energy for Goldsmith and Blacksmith workers [17]. The production of charcoal could either be by modern technology or traditional method. However for any method used, the wood should either be allowed to dry up naturally or be artificially dried before being carbonized.

For a long time charcoal was the only fuel and reducing agent used in iron production. Scarcity of wood in some countries caused the development of coke as an alternative fuel and today coke dominates even in most countries with large forest resources. Coke has become generally thought of as associated with the large, highly productive blast furnaces of today and it is then easy to think of charcoal as less efficient. Although the general trend has certainly been away from charcoal, charcoal blast furnaces are in operation in several countries and there are even plans for expanding some of these operations. Economic conditions vary both between countries and within them and it would therefore be of value to study the cases where charcoal is preferred in order to determine the relevant economic and technical factors. Unfortunately, it has not been possible to make a comprehensive study of the subject but certain data have become available which indicate that technical progress in forestry, charcoal production, and blast furnace operations have been of great significance [9]. Constantine [7], states that "under modern conditions charcoal can be as economic and efficient as coke for smelting iron ore in a standard blast furnace subject only to the provisions of adequate supply of raw materials." At the same time, several of the papers submitted to the present symposium point out the scarcity and high price of metallurgical coke, which often has to be transported over great distances. 
Furthermore, from my field survey it is evident that the few available cupola furnaces in Nigeria are conventional cupolas with poor energy efficiency while some other foundries using cupola furnaces have closed down as a result of cost of coke, scarcity of coke, absence of any proven fuel substitute to coke and dwindling profit margins. While the cost of Erythrophleum suaveolens charcoal per tonne is fourty thousand naira (\$250), the cost of coke per tonne ranges between ninety and one hundred thousand naira (\$625) in Nigeria. This therefore has necessitated the need to characterize erythrophleum suaveolens (E.s) charcoal in order to establish its viability as an alternative fuel to coke in iron melting.

\subsection{Charcoal as Metallurgical Fuel}

The use of charcoal as a smelting fuel has been experiencing a resurgence in South America following Brazilian law changes in 2010 to reduce carbon emissions as part of President Lula da Silva's commitment to make a "green steel" $[14,15]$.

Charcoal burns at intense temperatures, up to 2700 degrees Celsius. By comparison the melting point of iron is approximately 1200 to 1550 degrees Celsius [13]. Due to its porosity it is sensitive to the flow of air and the heat generated can be moderated by controlling the air flow to the fire. For this reason charcoal is an ideal fuel for a forge and is still widely used by blacksmiths. Charcoal is also an excellent reducing fuel for the production of iron and has been used that way since Roman times. In the 16th century England had to pass laws to prevent the country from becoming completely denuded of trees due to production of iron. In the 19th century charcoal was largely replaced by coke, baked coal, in steel making due to cost. Charcoal is far superior fuel to coke, however, because it burns hotter and has no sulfur. Until World War II charcoal was still being used in Sweden to make ultra high-quality steel. In steel-making, charcoal is not only a fuel, but a source for the carbon in the steel [13].

\subsection{Erythrophleum Suaveolens (Gwaska) wood}

Erythrophleum suaveolens is the tree whose charcoal is used in this research work. The vernacular names include; Forest ordeal tree, red water tree, sasswood tree (English). Boisrouge, poison d'épreuve, tali, grand tali, mancône (French) [18]. Gwaska (Hausa).

\section{Origin and geographic distribution}

Erythrophleum suaveolens is distributed from Senegal to Sudan and Kenya in the east and from there south to Zimbabwe and Mozambique. It has been introduced as an ornamental in tropical Asia [18]. This tree is also available in North Central and South West Nigeria.

\section{Uses}

The bark, traded as 'sassy-bark', 'mancona bark' or 'casca bark' is used as emetic and purgative. The crushed bark is applied to swellings caused by Filaria. In DR Congo the dried powdered bark is taken as a snuff to cure headache. In Kenya a diluted decoction of the roots is used as an anthelminthic, especially against tapeworm. In Malawi a decoction of the roots and bark is applied to soothe general body pain. Pieces of root or bark are a protective and love charm. The bark has been used in arrow poisons and as ordeal poison and the bark and leaves as fish poison. The use as an anaesthetic for fish in aquaculture is tricky as small differences in dosage will kill, rather than stupefy fish. In the Western world, bark extracts were used in the late $19^{\text {th }}$ century to treat heart failure [3]. Side effects and better results with digitoxine ended this practice. The tree produces quite hard, heavy and durable wood, marketed as 'alui', 'tali', 'erun', 'missanda' or 'sasswood', which is suitable for joinery, flooring, railway sleepers, harbour and dock work, turnery, construction and bridges. It is also used for boat building and wheel hubs. The bark has been used in West Africa for tanning hides and skins; it is used in DR Congo to colour leather brown. Erythrophleum suaveolens is planted as an ornamental and avenue tree. In West Africa the powdered bark is mixed with the residue of palm oil processing, and after boiling it is mixed with seeds of maize, cowpea or cotton, which effectively reduces pest damage to the seeds [5]. Dried leaves are mixed with stored grains and pulses to repel or kill storage insects. The use in agroforestry has been promoted: nitrogen fixation and the large amount of leaf litter are advantageous to intercrops. However, in experiments a negative effect of Erythrophleum suaveolens leaf mulch on the yield of crops has been noted. When clearing bush to prepare fields, trees are often left standing because the wood is hard and felling is too taxing. Erythrophleum suaveolens wood is not highly valued as firewood but charcoal made from it is excellent [18].

\subsection{Description}

Medium-sized tree up to 25(-30) $\mathrm{m}$ tall (Plate I), often branching low; bark finely fissured, scaly, grey; twigs glabrous. Leaves alternate, bipinnately compound with 2-4 pairs of pinnae; stipules minute, soon falling; petiole and rachis up to $35 \mathrm{~cm}$ long, petiole thickened at base; leaflets alternate, 7-14 per pinna, ovate to ovateelliptical, up to $9 \mathrm{~cm} \times 5.5 \mathrm{~cm}$, base asymmetrical, apex obtusely acuminate. Inflorescence an axillary panicle 
consisting of spike-like racemes up to $12 \mathrm{~cm}$ long, shortly yellowish hairy. Flowers bisexual, regular, 5 -merous, yellowish white to greenish yellow; pedicel c. $1.5 \mathrm{~mm}$ long, reddish hairy; calyx lobes $1-1.5 \mathrm{~mm}$ long; petals 2$3 \mathrm{~mm} \times 0.5 \mathrm{~mm}$, short hairy at margins; stamens 10 , free, c. $5 \mathrm{~mm}$ long; ovary superior, rusty hairy, 1-celled, stigma cup-shaped. Fruit a flat, slightly curved, dehiscent pod 5-17 cm $\times 3-5 \mathrm{~cm}$, stipe often lateral, broadly rounded at apex, pendulous, 6-11-seeded. Seeds oblong ellipsoid, $15 \mathrm{~mm} \times 11 \mathrm{~mm} \times 5 \mathrm{~mm}$ [18].

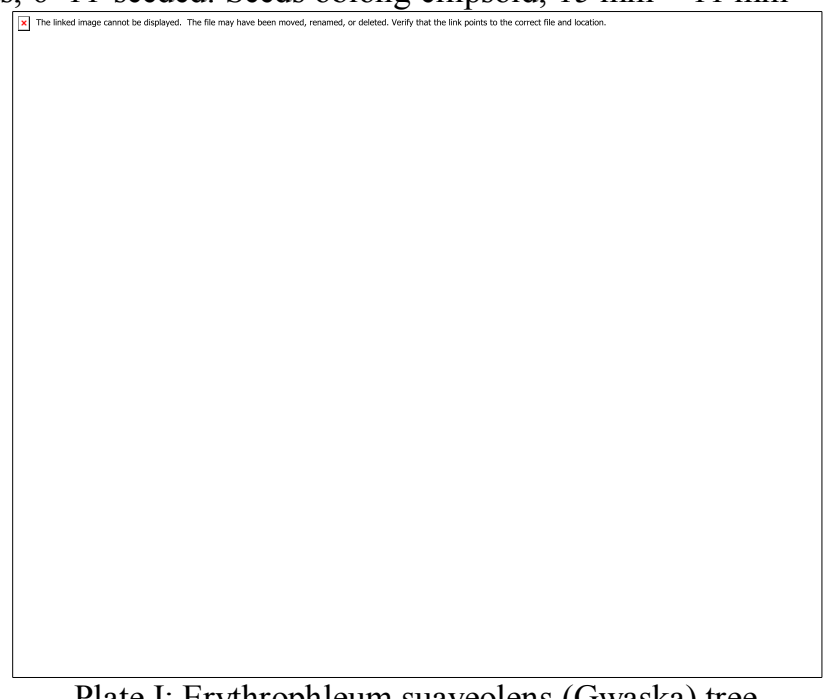

Plate I: Erythrophleum suaveolens (Gwaska) tree Source: Okeyo (2006)

\section{Characterization Of Erythrophleum Suaveolens Charcoal}

\subsection{Sample Collection}

The sample of erythrophleum suaveolens charcoal used in this work was sourced from a charcoal dealer based in Jos, Plateau state, Nigeria. The charcoal was produced by slow pyrolysis.

\subsection{Proximate Analysis}

Proximate Analysis involves determination for moisture, ash, volatile matter and fixed carbon. The methods used in this work were adopted from [1].

\subsubsection{Moisture content}

The silica crucible for the test was preheated at $105^{\circ} \mathrm{C}$ for 1 hour. One gramme of erythrophleum suaveolens charcoal sample was then placed in the crucible and heated at $105^{\circ} \mathrm{C}$ for 1 hour. The loss in weight accounts for the moisture content.

\subsubsection{Volatile matter}

The standard crucible was preheated in the muffle furnace at $970^{\circ} \mathrm{C}$ for 7 minutes. The crucible was cooled in the desiccators and 1 gramme of erythrophleum suaveolens charcoal sample was placed in it with three drops of benzene. The crucible (with the lid on) was now placed in the muffle furnace at $970^{\circ} \mathrm{C}$ for 7 minutes. The loss in weight accounts for the volatile content of the charcoal.

\subsubsection{Ash}

The standard silica crucible was preheated at $825^{\circ} \mathrm{C}$ for 1 hour. It was then cooled in the desiccators. One gramme of erythrophleum suaveolens charcoal sample was placed in the crucible (with the lid on) and it was heated at $825^{\circ} \mathrm{C}$ for 1 hour. The incombustible residue gives the ash content of the charcoal.

\subsubsection{Fixed carbon}

The fixed carbon is obtained from the relation:

Fixed carbon $\%=100-$ Moisture $\%$ - Ash $\%$ - Volatile matter $\%$

\subsubsection{Determination of total sulphur in erythrophleum suaveolens charcoal by Eschka method}

The method involves igniting 1g of charcoal sample and Eschka mixture (2 parts of magnesium oxide with 1 part anhydrous sodium carbonate). The sulphur is dissolved in water and then precipitated as barium sulphate. The precipitate is then filtered, ashed and weighed. The experimental procedure is as follows: One gramme of erythrophleum suaveolens charcoal sample was weighed into a $30 \mathrm{ml}$ porcelain crucible and mixed with $3 \mathrm{~g}$ of Eschka mixture. The blank and the standard sample were prepared in a similar manner. The crucibles 
were then placed in a cold muffle furnace and gradually heated to $800^{\circ} \mathrm{C}$ for about 60 minutes. The temperature was maintained for an additional 60 minutes. The crucibles were removed, slightly cooled and stirred to ensure that no black charcoal particles occur. The crucibles were them emptied into $400 \mathrm{ml}$ beakers containing $100 \mathrm{mls}$ of hot water. Digestion was done for 45 minutes, with occasional stirring. The solution in each beaker was now decanted through 540 filter paper into a $400 \mathrm{ml}$ beaker.

The insoluble material in the first beaker was thoroughly washed with hot water. After washing in this manner, the solid was transferred to the filter paper and washed 5 times with hot water. The filtrate volume was about $250 \mathrm{ml}$. The residue was then discarded. Three drops of methyl orange indicator was added. Sodium hydroxide was then added drop wise until just neutral.

Then, $1 \mathrm{ml}$ of hydrochloric acid was added to just acid and $25 \mathrm{ml}$ of potassium sulphate was also added using an 'A' grade pipette. The sample was now heated to boiling and $10 \mathrm{mls}$ of barium chloride solution was slowly added with stirring. The solution was maintained near boiling for 30 minutes and then stood overnight. The solution was then filtered with No 42 paper and washed well with hot water. The wet filter paper was placed into a crucible and ignited for 15 minutes. The paper was gradually smoked off in the muffle furnace, avoiding burning. The temperature was then gradually raised to $800^{\circ} \mathrm{C}$ and maintained for 1 hour. The crucible was cooled and barium sulphate weighted. Total sulphur is calculated as follows:

Total sulphur $\%=\frac{(A-B)}{C} \times 13.74$

Where $\mathrm{A}=$ mass of barium sulphate from sample

$\mathrm{B}=$ mass of barium sulphate from blank

$\mathrm{C}=$ mass of sample used

The results of the proximate analysis of Erythrophleum suaveolens charcoal are as presented in Table 1.

Table 1: Results of proximate analysis of Erythrophleum suaveolens charcoal

\begin{tabular}{lll}
\hline S/NO & Parameters \% & Erythrophleum Suaveolens charcoal \\
\hline 1 & Moisture & 0.94 \\
2 & Ash & 6.13 \\
3 & Volatile matter & 6.77 \\
4 & Fixed carbon & 86.16 \\
5 & Sulphur $(\mathrm{ad})$ & 0.003 \\
\hline
\end{tabular}

\subsection{Ultimate Analysis}

The ultimate analysis results (Carbon, Hydrogen, Oxygen and Nitrogen) of erythrophleum suaveolens charcoal were calculated using equations 25,26 and 27 as shown in Table 2. The calorific value of the charcoal sample was determined at the Grand Cereals Limited, Jos, Plateau State while Eschka method as described above was used to determine the total sulphur content of erythrophleum suaveolens charcoal as presented in Table 2.

Calculation of carbon and hydrogen from calorific value (Q) and volatile matter (VM) are given by equations 25 and 26 respectively [12].

$$
\begin{gathered}
C=0.59\left(\frac{Q}{2.3}+\frac{1.1 V M}{3}\right)+43.4 \\
H=0.069\left(\frac{Q}{2.3}+V M\right)-2.8 \\
\ldots .27
\end{gathered}
$$

Also oxygen was determined by using Seyler formula as presented below:

$Q=0.51883 C+1.625011-17.87+0.001(O)^{2} \mathrm{MJ} / \mathrm{Kg}$

Table 2: Results of ultimate analysis of Erythrophleum suaveolens charcoal

\begin{tabular}{lll}
\hline S/NO & Parameters & Erythrophleum Suaveolens charcoal (ad) \\
\hline 1 & $\%$ C & 77.5 \\
2 & $\%$ H & 9 \\
3 & $\%$ O & 5.48 \\
4 & $\%$ N & 1.89 \\
5 & \% Ash & 6.13 \\
6 & sulphur & $0.003(\mathrm{ad})$ \\
7 & Calorific value raw (Kcal./Kg) & 7158.6995 \\
\hline
\end{tabular}

Note: ad-as determined 


\begin{tabular}{lll}
\hline & \multicolumn{2}{c}{ Table 3: Proximate analysis of Ajaokuta coke sample } \\
\hline S/No & Parameters & Value $(\%)$ \\
\hline 1 & Moisture & 0.38 \\
2 & Ash (ad) & 13.45 \\
3 & Ash (db) & 13.50 \\
4 & Volatile matter (ad) & 2.34 \\
5 & Volatile matter (db) & 2.35 \\
6 & Volatile matter (daf) & 2.72 \\
7 & Fixed Carbon (ad) & 84.15 \\
8 & Fixed Carbon (daf) & 97.66 \\
9 & Sulphur (ad) & 0.14 \\
10 & Sulphur (db) & 0.14 \\
\hline
\end{tabular}

Source: Adeleke, et al (2006)

\subsection{Discussion of Characterization Results}

The moisture content of $0.94 \%$ for the erythrophleum suaveolens charcoal is higher than $0.38 \%$ obtained for Ajaokuta coke (Table 3) and exceeds the range required for the operation of the Ajaokuta Steel Plant blast furnace [11]. However the ash content of $6.13 \%$ is far lower than $13.45 \%$ reported for Ajaokuta coke within the limit required for Ajaokuta. Furthermore, the ash content of $6.13 \%$ determined is far lower than $24 \%$, for typical Indian coke [15].

The ash in coke is of great significance in the blast/cupola furnace operation. High ash lowers the carbon content and requires the use of more limestone as fluxes and thus the use of more energy for slagging. This results in increased coke rate and lower efficiency of the metallurgical process. It has been reported that $1 \%$ increase in ash causes an increase of $1.5-2 \%$ in coke rate, $1.5 \%$ in flux rate and lower blast furnace efficiency by $3-5 \%[15]$.

The volatile matter of $6.77 \%$ determined for the erythrophleum suaveolens charcoal is higher that $2.72 \%$ reported for Ajaokuta coke and within the upper limit of 30.3\% specified for Ajaokuta Steel Plant (Raw materials, 1994). Very high volatile generally reduce solid fuel output. The sulphur contents of $0.003 \%$ and $0.14 \%$ for erythrophleum suaveolens charcoal and coke meet the requirement for Ajaokuta $(0.9 \%)$ and is lower than $0.61 \%$ and $0.83-0.91 \%$ determined for Indian and German coke respectively [21]. The sulphur content is also lower than $0.48 \%$ reported for Chinese coke [4]. It is also lower than $0.55-0.60 \%$ in coke for efficient, high productivity blast furnace in United Kingdom [22]. Sulphur in iron can exist either as iron sulphide (FeS) or manganese sulphide (MnS). The ferrous sulphide forms brittle, low melting point, yellowish brown films round the solid cast iron or steel crystals and causes the metal to split when forged. It also tends to promote the formation of cementite and thus a harder iron [19]. The calorific value of $7158.6995 \mathrm{Kcal} / \mathrm{Kg}(30,066.54 \mathrm{~kJ} / \mathrm{kg})$ was determined for Erythrophleum suaveolens charcoal. The reported value of $30,500 \mathrm{~kJ} / \mathrm{kg}$ for coke by Eastop and McConkey [8] showed that erythrophleum suaveolens charcoal can compete favourably with coke.

\section{Conclusion}

The following could be concluded from this work:

i. The characterization showed that the ash content of $6.13 \%$ for Erythrophleum suaveolens charcoal is lower than $13.45 \%$ reported for Ajaokuta coke and is far lower than $24 \%$, for typical Indian coke. This may result in decreased erythrophleum suaveolens charcoal rate and higher efficiency of the metallurgical process.

ii. The sulphur contents of $0.003 \%$ and $0.14 \%$ for erythrophleum suaveolens charcoal and coke meet the requirement for Ajaokuta and is lower than $0.61 \%, 0.48 \%, 0.55-0.60 \%$ and $0.83-0.91 \%$ determined for Indian, Chinese, United Kingdom and German coke respectively. This lower sulphur content will prevent the metal from splitting when forged and it will also reduce the formation of cementite and thus a softer iron.

iii. The calorific value of 30,066.54kJ/kg determined for Erythrophleum suaveolens charcoal, when compared with the reported value of $30,500 \mathrm{~kJ} / \mathrm{kg}$ for coke showed that there was no significant difference between the calorific values of coke and Erythrophleum suaveolens charcoal.

iv. The above deductions showed that erythrophleum suaveolens charcoal's thermal properties can compete favourably with that of coke and therefore can be an excellent reducing fuel for the production of iron. Also the low sulphur content shows that erythrophleum suaveolens charcoal is more environmentally friendly than coke.

\section{RECOMMENDATIONS}

1. Erythrophleum suaveolens is an important medicinal plant and further study of its pharmacology is justified. 
2. The charcoal made from it is excellent. Therefore, breeding and management programmes should be started in our country (Nigeria) to enhance deliberate propagation and establishment of erythrophleum suaveolens (Gwaska) tree in our indige-nous forests and plantations.

3. Nigeria has lost over N1 billion (U\$6M) to illegal export of charcoal and logs from states in the South West and North Central to the Middle East and Europe in the last four years [2]. Therefore, government should prevent this and ensure that the charcoal and logs are retained for the use of local foundries.

\section{Acknowledgement}

This work was supported by Grand Cereals Limited, Jos, Plateau State and Department of Mechanical Engineering Technology, Federal Polytechnic, Bauchi. Therefore, the need to appreciate the Managements of these two organizations for allowing the use of their quality control and thermodynamic laboratories facilities respectively.

\section{References}

[1]. Adeleke, A.O., Makan, R.S. and Ibitoye, S.A. (2006). Characterization of Ajaokuta Coke for Blast Furnace Iron making. Journal of Minerals \& Materials Characterization \& Engineering, jmmce.org Vol. 5, No.2, pp 155-165. Printed in the USA. All rights reserved.

[2]. Alex, Abutu. Nigeria's Federal Government Loses N1 Billion to Illegal Charcoal, Wood Export. http://allafrica.com/stories. Retrieved 2012-11-20

[3]. Ayensu, E.S., 1978. Medicinal plants of West Africa. Reference Publication, Michigan. P 330

[4]. Brouwer, R. C., Schoone, E.E. and Toxopeus, H.L., (1992). "Coal Injection driven to the limits", Iron and Steel Engineer, Vol. 69, No 12, pp. 22.

[5]. Burkill, H.M., 1995. The useful plants of West Tropical Africa. 2nd Edition. Volume 3, Families J-L. Royal Botanic Gardens, Kew, Richmond, United Kingdom. P 857.

[6]. CAD., 1991. Wood for Energy in Nigeria, Center for Agric. Development, pp: 15-18

[7]. Constantine, A. Charcoal blast furnace operations, Wundowie, W. Australia. International symposium, 1963.

[8]. Eastop, T.D. and McConkey, A. (1993), Applied Thermodynamics for Technologists. Longman Singapore Publishers.

[9]. FAO STAFF. Paper prepared for a United Nations interregional Symposium on the Application of Modern Technical Practices in the Iron and Steel Industry in Developing Countries, 1983.

[10]. FAO., 1990. The major significance of Minor forest products Rome, pp; 49.

[11]. Federal Ministry of Mines, Power and Steel circular, (1992), on Carbonization tests for Ajaokuta coke requirements, Lagos, Nigeria.

[12]. Francis, W. Peters M C (ed) (1980). Fuels and Fuels Technology. Pergamon, New York.

[13]. http://en.wikipedia.org/wiki/file:charcoal. Retrieved 2012-06-23

[14]. M. Kato1, D. M. DeMarini, A. B. Carvalho, M. A. V. Rego, A. V. Andrade1, A. S. V. Bonfim and D. Loomis (2004). "World at work: Charcoal producing industries in northeastern Brazil". http://oem.bmj.com/content/62/2/128.full. Retrieved 16 September $\underline{2012}$

[15]. Michael Smith and David Voreacos (January 21, 2007). "Brazil: Enslaved workers make charcoal used to make basic steel ingredient". Seattle Times. http://www.corpwatch.org/article.php?id=14328. Retrieved 16 September 2012.

[16]. Moitra, A.K., Banerjee, N.G. Shrinkhande, K.Y., Sing, K. Raja, K. and Banerjee, S (1992): Studies on coal carbonization in India, Central Fuel Research Institute (CFRI) publication, Calcutta.

[17]. Ogunsanwo, O.Y., Aiyloja, A.A. and Uzo, C. (2007). Production Techniqueand the Influence of Wood Species on the Properties of Charcoal in Nigeria, A Case Study of Oyo State. Agricultural Journal 2 (1).

[18]. Okeyo, J.M., 2006. Erythrophleum suaveolens (Guill. \& Perr.) Brenan. In: Schmelzer, G.H. \& Gurib-Fakim, A. (Editors). Prota 11(1): Medicinal plants/Plantes médicinales 1. [CD-Rom]. PROTA, Wageningen, Netherlands.

[19]. Rollason, E.C., (1973). Metallurgy for Engineers, The English Language Book Society and Edward Arnold Publisher.

[20]. $\wedge$ "Using charcoal efficiently". http://www.fao.org/docrep/X5328E/x5328e0b.htm. Retrieved 2010-02-01.

[21]. Weskamp, W., Rhode, W., Stewen, E., and Habermehl, D., (1987). "Greater coke strength through reactive additives to coking blends", $1{ }^{\text {st }}$ International Cokemaking Congress, Essen, Section III. I.

[22]. Willmers R.R. and Bennington, C.R., (1992). "Coke quality requirements for efficient, high productivity blast furnace operation at high coal injection rates", $2^{\text {nd }}$ international coke making congress, London, pp. 275. 